\title{
The Influence of Learning Strategies on the Mathematics Achievement of Students as It Relates to School Factors
}

\author{
Judith Hannah OSARUMWENSE (Ph.D) \\ Department of Educational Evaluation and Counselling Psychology \\ Faculty of Education, University of Benin \\ Kate OTEZE \\ Department of Curriculum \& Instructional Technology, Faculty of Education, University of Benin
}

\author{
DOI: $10.7176 / \mathrm{JEP} / 10-13-06$ \\ Publication date:May $31^{\text {st }} 2019$ \\ Introduction
}

Mathematics is usually seen as the language of science and technology. Without doubt, it is the bedrock for technological advancement of any country and a requirement for effective study of other school subjects in areas like numbers and numeration, variation, graphs, fractions, equations and also in volume. Hence, it was made compulsory for all students from Basic Education up until senior secondary school level. In spite of its importance, the performance of students in the subject has been a great concern to the society as poor performance is obtained year after year in the subject by students. For example, Zalmon and Wonu (2017) shown the percentage performance of students from year 2010 to year 2016 in Mathematics for grade levels $\mathrm{A}_{1}-\mathrm{C}_{6}$ as follows; 33.55\%, $38.93 \%, 49.00 \%, 36.00 \%, 31.30 \%, 34.18 \%$ and $38.68 \%$ for $2010,2011,2012,2013,2014,2015,2016$ respectively.

Mathematics is expected to be well learned by students due to its importance but it is a subject most students find difficult to learn effectively. To effectively learn the subject, Mathematical intelligence is a tool that must be possessed by the students. Gardner (2001) in Elmore (2002) identified logical/Mathematical intelligence as one of the eight (or more) intelligences that people have and that people vary considerably in the innate levels of Mathematical intelligence that they are born with. Elmore (2002) noted that a certain amount of Mathematics knowledge and skill is innate - genetic in origin. Elmore (2002) was of the view that Mathematics learning is based on natural endowment (nature) and environmental influences (nurture). He however stressed that Mathematics knowledge and skills come from excessive learning by engaging part of the brain to learn Mathematics content the brain was not naturally designed to learn being that the brain can greatly accommodate large contents of information or knowledge.

Two basic factors that enhance Mathematical knowledge, skills, and interest are genetic makeup of the individual and environment they grow up. The two factors help to shape the level of Mathematical skills that the individual student can acquire. Therefore, for Mathematics to be effectively learned, various methods have to be employed by all stakeholders to arrest the interest of students (Elmore, 2002). Thus, deliberate and dedication in the learning of Mathematics can go a long way to enhance better understanding of the subject. This is because learning involves strengthening correct responses and weakening incorrect responses as well as making sense of the presented material by attending to relevant information, mentally reorganizing it and connecting it with what is already known (Clark \& Mayer in Malamed, 2019).

Therefore, for students to effectively benefit from the learning process, they need to effectively and intentionally strategize plans of actions that will enable them to meaningfully learn. Learning strategies involves students' self generation of thoughts, feelings, and actions which are systematically oriented toward attainment of their goals (Hasanbegovic, 2019). Also, learning strategies according to Freeman (2004) is an individual's way of organizing and using a particular set of skills in order to learn content or accomplish other tasks more effectively and efficiently in school as well as in non academic settings. Oxford (1990) noted that the use of specific actions, procedures to promote one's own learning is known as learning strategies.

Primary English Community (2013) noted that strategies employed by students to learn become a useful tool kit for active, conscious, and purposeful self-reputation when the learner deliberately apply strategies that fit his or her learning strategies. The primary English community (2013) also emphasized that more successful learners are those who know many learning strategies, able to decide on which strategies to use and apply the chosen strategies in a deliberate and consistent manner as well as use learning strategies that suit their learning styles.

Learning strategies of students have been found to positively and highly correlate with Mathematics performance of students (Osarumwense, 2015). Pintrich and DeGroot (1990) also found in their study that the use of good cognitive strategy and self-regulation (meta-cognitive) highly relate to high academic achievement of students and that poor performance of students is usually as a result the students not using high self regulation strategies.

Environmental factor has been traced to effective Mathematics learning (Elmore, 2002). In this study, environmental factors were viewed as school related factors. School factors could be viewed with respect to 
ownership and location. The owner of a school has significant role to play in the goal actualization of the school. This is because, the owner has full right to decide on the level to raise the school up to and how the school should be adequately run. Schools attended by students can greatly influence their academic achievement. When schools are in good form that is, having standard structures, well equipped with learning facilities and having sound, dedicated, qualified and experienced teachers to teach, the students will be motivated to learn. The owner of the school whether government or private individual does not actually have any influence on the academic achievement of the students, but what influences the academic achievement of students are adequate provision of conducive learning environment, human and material learning facilities and the individual student' learning styles and strategies.

School owned by private individual or government and situated either in urban or rural or suburban areas, so long as the school is adequately furnished with learning facilities such as well furnished library, well equipped laboratories, adequate sitting facilities well built and well equipped classrooms, well equipped staff offices, adequate and constant power supply and other basic useful facilities as well as supply of required number of members of staff. Such school is bound to actualize its goals. Another crucial aspect of consideration about school factors is the location of the school. The place where a school is situated is of paramount importance to the effective running of the school. School location simply describes the settlement or area in which a school is situated. This settlement could either be urban or rural or suburban. To Chianson (2012), the area where school is located has significant influence on the achievement of students. Brown and Swanson (2001) noted that differences that exist in students' achievement could be due to school factors such as the area where the school is situated, provision of technology and adequate supply of qualified teachers. Although, the differences that exist between urban and rural schools and between public and private schools are not in the name location or ownership but in inequality in the provision of adequate school facilities.

However, in most parts of Africa and Nigeria in particular, there is great difference between government owed schools and most schools owed by private individuals as the above mentioned learning motivational opportunities are not provided for in most government owned schools (Osarumwense \& Oyedeji, 2011). For example, Federal Ministry of Education (FME, 2016) found in their study that teacher/pupil ratio in Nigerian public primary schools was 1:49 and in Edo State in particular was 1:42. However, in private owed schools, the ratio was 1:15. Okeogeohene (2019) also found out that most public schools lack necessary instructional and infrastructural facilities. Hawwau (2015) found out in his study that there are functional libraries in private schools but non-functional libraries in public schools and that school libraries are funded through student levy in some schools in Akinyele LGA of Oyo state.

Lubienski and Lubienski (2006) also noted that the differences in Mathematics performance of students in public and private schools are traceable to differences in demographic factors that exist between the two schools. They however found out that when public schools are provided with similar features in private schools, the students perform as high as the private school students. By implication, the difference in performance of students in public and private schools is as a result of the differences in the supply of adequate school facilities. So, if both public and private schools are provided with equal school facilities, the students are likely to perform equally. They therefore argued based on their findings that private owned schools are not better than public owned schools. They suggested that government should reform public schools to enhance effective learning of students in such schools.

\section{Statement of the Problem}

There have been mixed findings by researchers over influence of learning strategies on students' achievement with reference to school related factors. For example, Shodhganga (2007) found that there is no significant difference in cognitive styles and intelligence abilities of students in private and public schools. The study of Jafari, Shafie and Asadollahi (2013) revealed that students schooling at different locations such as urban and rural have similar views and that private and public school students also have similar views. However, Chen, Ferron, Gorin and Thompson (2005) found that 22 out of 23 cognitive attributes such as cognitive skills, knowledge of students as well as learning strategies that students employ aid students in urban schools to demonstrate superiority over students in rural schools in the mastery of cognitive attributes they use in solving Mathematical problems. They also found that students in urban schools possess higher mastery ability in difficult Mathematics topics especially in Algebra, Geometry and areas that requires abstract thinking and reasoning skills majorly in areas that require proportional reasoning and logical reasoning.

Shodhganga's (2007) found that there is significant difference in the intelligence and achievement of boys and girls and their achievement motivation. More so, it was found that male science students in urban schools cope better with learning than rural science students. On the part of the female students, their learning strategies and intellectual abilities of those in urban schools significantly differ from those in rural schools. The study also found that the urban students were more academically aspirant than rural students. However, rural students performed higher in test that requires reasoning ability despite the fact that their reasoning ability was influenced by their locality. 
Chauhan (2004) found that the preferences for different learning style of government male and female school students living in urban and rural areas were influenced by their locality. Urban and rural school students did not differ significantly in their cognitive style however, the urban school students performed better. To Schoenfeld (2002), without doubt students living in the rural areas will end up dropping out of science and Mathematics field due to low availability of resources aids and poor visibility. Li and Willing (2002) noted that almost all schools if not all lack internet facilities and the use of technology because they are economically disadvantaged. Although they noted that schools in the urban areas have similar problems but however concluded that rural schools are at higher disadvantage.

More so, there are standard private and public owed schools in some rural areas in Edo State like Lumen Christy owed by the Catholic Church and Federal Government School at Ibilo which is owed by Federal Government. Also, there are some standard government schools in urban areas as well as so many non standard and poorly furnished private schools in the urban areas of Edo State. One would begin to wonder if these mixed standards were the observed in areas where other researchers carried out their studies. Hence, the researchers deemed it necessary to investigate the influence of learning strategies on the Mathematics achievement of students as it relates to school factors.

\section{Research Questions}

The following research questions were raised for the study

1 Is there a difference in the relationship between Mathematics learning strategies of students and their academic achievement in Mathematics by school ownership?

2 Is there a difference in the relationship between Mathematics learning strategies of students and their academic achievement in Mathematics by school location?

\section{Hypotheses}

The two research questions were hypothesized for the study as follows:

1 There is no significant difference in the relationship between Mathematics learning strategies of students and their academic achievement in Mathematics by school ownership.

2 There is no significant difference in the relationship between Mathematics learning strategies of students and their academic achievement in Mathematics by school location.

\section{Purpose of the Study}

The study aimed to determine the influence of learning strategies employed by public and private school students and those of urban and rural school students and their academic excellence in Mathematics and to also determine the difference in relationship between learning strategies and achievement in Mathematics based on school ownership and location.

\section{Methodology}

The study employed correlation research design. All junior and senior secondary school students in Edo South Senatorial District made up the population of the study. A sample size of 280 students was used for the study. Multistage sampling techniques were used to select the sample. First of all, Edo South Senatorial District was selected using purposive sampling technique. The choice of this senatorial district was based on the fact that it is the district with the highest Local Government Areas. Secondly, equal stratified random sampling technique was used to select two (02) secondary schools (one public and one private) from each LGA in Edo South Senatorial District. Thirdly, simple random sampling technique was used to select five (05) students from JS2 and five (05) students from JS3 and also, five (05) students from SS2 and five (05) students from SS3 which made it twenty (20) students from each school and 280 from the senatorial district. On the whole, 160 male students which is $57 \%$ of the sample and 120 female students which is $43 \%$ of the sample were used for the study.

Questionnaire was used for data collection. The questionnaire is a developed standardized scale that was developed by Osarumwense (2015). The reliability of the instrument was .89 which shows that the instrument is highly reliable. The questionnaire consisted of two sections: A and B. section A sought for demographic data such as name of school, school ownership, sex, identification code to enable the researchers identify the Mathematics scores of students. Section B was based on items addressing on the study. Also, the Mathematics scores for the 2013/2014 third term results were collected from the vice principals of the sampled schools and the scores were standardized using $\mathrm{Z}$ and $\mathrm{T}$ scores to allow for comparison from one school to the other. The data obtained from the questionnaire Mathematics standardized scores were correlated using Pearson Product Moment Correlation and Fishers' $\mathrm{Z}$ to determine the difference in relationship. 


\section{Hypotheses Testing}

Results

Hypothesis 1: There is no significant difference in the relationship between learning strategies and academic achievement of students in Mathematics by school ownership.

Table 1: Fishers' Z Statistics on Differences in Relationship by School Ownership.

\begin{tabular}{llllll}
\hline School type & $\mathrm{N}$ & $\mathrm{R}$ & $\mathrm{Zr}$ & $\mathrm{Z}$ - Critical & Z-calculated \\
\hline Public & 135 & .728 & .9287 & 1.96 & 1.8180 \\
Private & 145 & .611 & .7089 & & \\
\hline
\end{tabular}

Results in Table 1 show that the calculated Z-valued of 1.82 is less than the critical Z-value of 1.96 at .05 alpha level therefore, the null hypothesis is retained. It is therefore concluded that, there is no significant difference between the correlation coefficients computed for public and private school students. Learning strategies have no differential influence on achievement in Mathematics for both public and private school students. Therefore, learning strategies influence achievement in Mathematics of both public and private secondary school students in the same way.

Hypothesis 2: There is no significant difference in the relationship between learning strategies and academic achievement of students in Mathematics by school location.

Table 2: Fishers' Z Statistics on Differences in Relationship by School Location.

\begin{tabular}{llllll}
\hline Location & $\mathrm{N}$ & $\mathrm{R}$ & $\mathrm{Zr}$ & Z-Critical & Z-calculated \\
\hline Rural & 135 & .728 & .9287 & 1.96 & 1.4103 \\
Urban & 145 & .638 & .7589 & & \\
\hline
\end{tabular}

Results in Table 2 show that the calculated Z-value of 1.41 is less than the critical Z-value of 1.96 at .05 alpha level therefore, the null hypothesis is retained. It is therefore concluded that, there is no significant difference between the correlation coefficients computed for rural and urban school students. Learning strategies have no differential influence on achievement in Mathematics for both rural and urban school students. Therefore, learning strategies influence achievement in Mathematics of both rural and urban secondary school students in the same way.

\section{Discussion of Findings}

The findings of this study revealed that learning strategies influence achievement in Mathematics of both public and private school students in the same way. The findings of this study is in line with that of Shodhganga (2007) who studied learning styles of high school students and found that there is no significant difference between the cognitive styles and intelligence of government and private school students at 0.05 alpha level. Jafari, et al (2013) found no significant difference as well between the views of students based on school location and school type. To Osarumwense and Oyedeji (2011), School ownership is not supposed to influence achievement if both public and private owned schools are well equipped with the necessary learning facilities and are provided with conducive learning environment. The findings of this study could be due to the fact that most public owned schools in Edo State is presently comparable to most private owned schools due to the effort put in by the past and present administration to raise public owned schools to an appreciable standard.

The findings of this study also show that learning strategies influence achievement in Mathematics of both rural and urban school students in the same way. However, the relationship between learning strategies and academic achievement of rural school students were higher than that of urban school students as a higher correlation coefficient was obtained for rural school students. This higher correlation between rural school students' learning strategies and academic achievement, contradicts the finding of Shodhganga (2007) who found in his study that the achievement motivation of boys and girls is highly related to their intelligence and achievement. Secondly, they also found that male science students in urban area adjust better than their female science counterpart.

The study of Shodhganga (2007) revealed that female students living in urban and rural areas differ in their learning style and mental abilities. It was also shown that the reasoning ability test scores of students living in the rural area are higher than students living in the urban area and that locality where they dwell had impact on the way the reason. Chauhan (2004) found that urban and rural school students do not significantly differ in their use of cognitive learning style but it was however found that the urban school students had higher mean score. The findings of this study could be due to the fact that learning strategies employed by both rural and urban school students may be pointing to the same level as there has been little or no power supply in most States of the Federation for over a year now. Constant power supply could make urban school students study better than those in the rural areas but the state of power supply in the Cities has not made any difference between rural and urban areas. Most importantly, urban school students' attention to learning could be influenced negatively by 
technological engagement (internet facilities) which most often is not based on educational advancement but on social activities. Most rural school students are not opportune to be engaged in technological activities and as such, could be drawn closer to their studies.

\section{Conclusion}

Based on the findings, the researchers conclude that the learning strategies of students highly correlate with their achievement in Mathematics and that there is no significant difference by school ownership and school location in the relationship between learning strategies and achievement of students in Mathematics

\section{Recommendations}

Based on the findings of this study, the following recommendations are made

1 Teachers, parents, and school counsellors should encourage students to employ the different learning strategies in studying Mathematics so as to have high achievement in Mathematics.

2 Parents, teachers and counsellors should encourage students to use more of cognitive learning strategies in studying Mathematics as it contributes more to achievement.

\section{REFERENCES}

Brown, D. \& Swanson, L. (2001). Rural education: Student achievement. Retrieved from Sitemeller. Umich edu/butler/356/stud....Accessed 12/04/2013.

Chauhan, R. S. (2004). A study of learning styles of high school students in the context of their adjustment and extroversion-introversion. Indian Educational Abstract, 4(1): 83-84

Chen Y., Ferron, J. M., Gorin J. S. \& Thompson, M. S. (2005) Running head. Subgroup comparison of mathematics performance: from a perspective of cognitive attributes.

Chianson, M.M. (2012). School location as a correlate of mathematics students' achievement in cooperative learning class. Journal of Education and Leadership Development, 4, 42-46.

Elmore, R.F (2002). Constructivism: Situated learning and other learning theories. Retrieved online http://otec.uoregon.edu/learning theoty.htm. Accessed 29/08/2013

Federal Ministry of Education (2016). Nigeria education indicators. Retrieved from www.nemis.gov.ng on the 27/3/2019.

Freeman, R. J. (2004). Learning strategies; the educators guide to learning disabilities and attention deficit hyperactivity disorder. Retrieved from wwwidonline.org > article on 23/4/2019.

Hasanbegovic, J. (2019). Learning strategies. Retrieved from edutechwiki.unige.ch on the 23/4/2019.

Hawwau, M. (2015). Student's utilization of secondary school libraries in Akinyele LGA of Oyo State. Journal of Research of Methods in Education, 5(3): 60-66.

Jafari, S. E. M., Shafie, M. M. \& Asadollahi, M. V. (2013) Investigation of the utilization amount of the meta cognitive strategies Retrieved on the 6-4-2014 from www.iiste.org.

Li, Q. \& Willing, L. (2002). Technology-girls: Technology enhanced gender inclusive role-model learning system. Grant application to national science foundation. University of NorthDakotas

Lubienski, C. \& Lubienski, S.T. (2006). Charter, private, public schools and academic achievement. New evidence from NAEP mathematics data. National centre for the study of privatization in education teachers college. Columbia University. New York.

Malamed, C. (2019). Ten definitions of learning. Retrieved from theelearningcoach.com $>$ cognition on the $23 / 4 / 2019$.

Okeogeoghene, E. (2019). Evaluating the 6-3-3-4 system of education in Nigeria. Retrieved from thepointernewsonline.com on the 26/02/2019.

Osarumwense, J. H. (2015). Construction, validation and standardization of Mathematics learning strategies scale for secondary school students. Unpublished doctorate dissertation submitted to the office of post graduate studies of the University of Benin, Benin City.

Osarumwense, H. J. \& Oyedeji, S. O. (2011). Learning environment: a sine qua non to learning Mathematics. Journal of Education, Health and Technology Research (JEHERT), 1(1) 111-116.

Oxford, R. L. (1990). Language learning strategies: What every teacher should know. Retrieved on the 10-6-2013 from ndrc.org.

Pintrich, P. R., \& DeGroot, E. V. (1990) Motivational and self-regulated learning component of classroom academic performance. Journal of Educational Psychology, 82(1): 33-40.

Primary English Community (2013) An inventory of useful learning strategies. Retrieved on the 15-1-2014 from http://educate2.ch/pec

Schoenfeld, A. (2002). Making mathematics work for all children: Issues of standards, testing and equity. Educational Researcher, 3(1):13-25.

Shodhganaga (2007) Review of related literature. Retrieved in the 10-5-2014 from Shodhganga. 
Inflibret.acin/bitstream.

Zalmon, I. G. \& Wonu, N. (2017). Comparative analysis of students mathematics achievement in West African Examination Senior Secondary Certificate Examination in Nigeria. European Journal of Research and Reflection in Educational Sciences. 5(1), 24-31. 